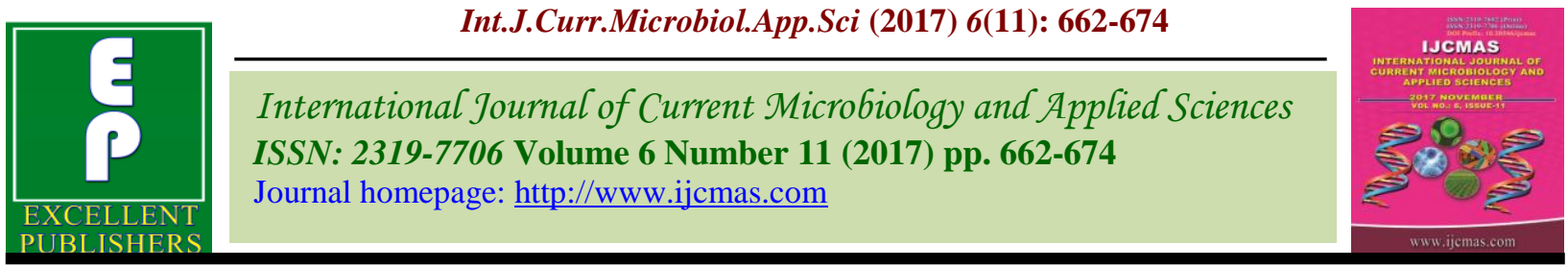

Review Article

https://doi.org/10.20546/ijcmas.2017.611.079

\title{
Synthetic Seed Technology
}

\author{
M. Mudasir Magray*, K.P. Wani, M.A. Chatto and H.M. Ummyiah \\ Division of vegetable sciences, SKUAST-K, Srinagar, India \\ *Corresponding author
}

\begin{tabular}{|c|c|}
\hline & A B S T R A C T \\
\hline & Synthetic seeds are defined as artificially encapsulated somatic embryos, shoot \\
\hline Keywords & $\begin{array}{l}\text { buds, cell aggregates, or any other tissue that can be used for sowing as a seed } \\
\text { and that possess the ability to convert into a plant under in vitro or ex vitro }\end{array}$ \\
\hline $\begin{array}{l}\text { Synthetic seed. } \\
\text { Micro propagules, } \\
\text { Sporogenesis }\end{array}$ & $\begin{array}{l}\text { conditions and that retains this potential also after storage. Earlier, synthetic } \\
\text { seeds were referred only to the somatic embryos that were of economic use in } \\
\text { crop production and plant delivery to the field or greenhouses (Gray, et al., }\end{array}$ \\
\hline Article Info & 1991). Implementation of synthetic seed technology requires manipulation of \\
\hline $\begin{array}{l}\text { Accepted: } \\
\text { 07 September } 2017 \\
\text { Available Online: } \\
10 \text { November } 2017\end{array}$ & $\begin{array}{l}\text { able to convert into plants, for encapsulation, somatic embryogenesis, } \\
\text { organogenesis and enhanced auxiliary bud proliferation systems are the } \\
\text { efficient techniques for rapid and large scale in vitro multiplication of elite and } \\
\text { desirable plant species. }\end{array}$ \\
\hline
\end{tabular}

\section{Introduction}

In general there are two types of seeds which can be used for propagation of plants and thus help in the maintaining the survival of plants in nature:

Natural Seed

Artificial Seed

\section{Natural Seed}

The seed stage of seed plants represents a unique developmental phase of the spermatophyte life-cycle, and as such involves structures, not characteristic of other stages of development. The essential structure of seed is defined as a ripened ovule consisting of an embryo and its coat. The normal seed contains materials which it utilizes during the process of its germination. There substances are frequently found in the endosperm. Thus endosperm may contain variety of stored materials such as starch, oils, proteins etc. In some plants, however, the reserve food material is present in cotyledons.

\section{Importance of natural seed}

The seed provides an expedient living unit for the study of wholeness that is a complex of biological factors which can be considered simultaneously. The seed occupies that sector of an organism life cycle form mega sporogenesis (genetic) to the formation of seedling (ecological). However, a seed is not truly a reproductive structure, but rather an adaptive mechanism to facilitate suspending 
growth and interrupting the coutinum of homeostasis in the life cycle.

Seeds are the corner stone of agriculture because when seeds are planted in the soil and given water, nutrients, light and some protection from pests would reproduce plant and seeds identical to that planted and also produce number of seeds which could be used for food or feed.

\section{Synthetic seeds}

Synthetic seeds are defined as artificially encapsulated somatic embryos, shoot buds, cell aggregates, or any other tissue that can be used for sowing as a seed and that possess the ability to convert into a plant under in vitro or ex vitro conditions and that retains this potential also after storage.

Earlier, synthetic seeds were referred only to the somatic embryos that were of economic use in crop production and plant delivery to the field or greenhouses (Gray et al., 1991). In the recent past, however, other micropropagules like shoot buds, shoot tips, organogenic or embroyogenic etc.

Implementation of synthetic seed technology requires manipulation of in vitro culture systems for large scale production of viable materials that are able to convert into plants, for encapsulation, somatic embryogenesis, organogenesis and enhanced auxiliary bud proliferation systems are the efficient techniques for rapid and large scale in vitro multiplication of elite and desirable plant species. Through these systems a large number of somatic embryos or shoot buds are produced which are used as efficient planting materials as they are plant regeneration either after having minor treatment or without any treatment with growth regulator(s). Because the naired micropropagules are sensitive to desiccation and / or pathogens when exposed to natural environment, it is envisaged that for large scale mechanical planting and to improve the success of plant (in vitro derived) delivery to the field or greenhouse, the somatic embryos or even the other micropropagules useful in synthetic seed production would necessarily require some protective coatings. Encapsulation is expected to be the best method to provide protection and to convert to in vitro derived propagules into synthetic seeds of a number of plant species belonging to angiosperms and gymnosperms (Table 1). Nevertheless, their number is quite small in comparison to the total number of plant species in which in vitro regeneration system has been established.

\section{Technology}

Basic hindrance to synthetic seed technology was primarily based on the fact that the somatic embryos lack important accessory tissues, i.e., endosperm and protection coatings, that make them in convenient to store and handle (Renden baugh, et al., 1993). Furthermore, they are generally regarded to lack a quiescent resting phase and to be incapable of undergoing dehydration. The primary goal of synthetic seed research was, therefore, to produce somatic embryos that resemble more closely the seed embryos in storage and handling characteristics so that they can be utilized as a unit for clonal plant. Propagation and germplasm conservation. In achieving such a goal the technology of encapsultation has evolved as the first major step of production of synthetic seeds. Later it was thought that the encapsulation synthetic seeds should also contain growth nutrients, plant growth promoting micro-organisms (e.g., micorrhizae), and other biological components necessary for optimal embryo-toplant development. The choice of coating material for making synthetic seeds is also an important aspect for synthetic seed production. 
Based on the technology established so far, two types of synthetic seeds are known desiccated and hydrated. The desiccated synthetic seeds are produced from somatic embryos either naked or encapsulated in polyethylene glycol followed by their desiccation. Desiccation can be achieved either slowly over a period of one or two weeks sequentially using chambers of decreasing relative humidity or rapidly by unsealing the pier dishes and leaving then on the bench overnight to dry. Such types of synthetic seeds are produced only in plant species whose somatic embryos are desiccation tolerant. On the contrary, hydrated synthetic seeds are produced in those plants where the somatic embryos are recalcitrant and sensitive to desiccation. Hydrated synthetic seed are produced by encapsulating the somatic embryos are hydrogel capsules.

\section{History of synthetic seeds}

The origin of the idea of an artificial seed is difficult to determine. Certainly, those who first produced somatic embryos may have considered such application (Steward, et al., 1958 and Reinert, 1958). The discovery of somatic embryogenesis in carrot in the year 1958 was almost simultaneously by F. C. Steward (USA) and J. Reinert (Germany). F. C. Steward a renowned plant physiologist at Cornell University in New York. However, it was not until the early 1970's that the concept of using somatic embryos began to be presented as a potential propagation system for seed sown crops. Toshio Murashige gave a number of survivors in tissue culture propagation where he concluded with this concept. He formally presented his ideas on artificial seeds at the symposium on tissue culture for horticultural purposes in Belgium, September 6-9, 1977. His terse comments in the proceedings, however, were to be applicable, the cloning method must be extremely rapid, capable of generating several million plants daily and competitive economically with the seed method (Mugashinge, 1977).

Drew (1979) was active in developing methods to commercially propagate crops using somatic embryos. He suggested delivering carrot somatic embryos in a fluid drilling system, but was able to produce only three plants from carrot embryos on a carbohydrate free medium. He could not get success in producing many plants through this system. He faced a crucial problem and found the very slow rate of development of plantlets derived from culture. Kitto and Janick (1982) coated dumps of carrot embryos, roots and Cellus with polyongethylene. Some embryos survived the coating process as well as a desiccation step (Kitto and Janick, 1985a and 1985b). The early assessment of Murashigesirect (1977) on the difficulty of somatic embryogeny are still valid today. The quality and fidelity of somatic embryos are the limiting factors for development and scale up of artificial seeds.

Interestingly, artificial seed prepared from shoot buds can also be used for plant propagation and this was reported by $\mathrm{P}$. S. Rao's group from BARC, Mumbai. Research on artificial seeds in rice is still in infancy and this technology through somatic embryogenesis, would offer a great scope for large scale propagation of superior, elite hybrids (Brar and Khush, 1994).

\section{Potential uses of artificial seeds}

Delivery system

Reduced costs of transplants

Direct greenhouse and field delivery of elite, select genotypes, hand pollinated hybrids, genetically engineered plants, sterile and unusable genotypes, large seed monocultures, mixed genotype plantations. 
Carrier for adjuvant such as micro-organisms, plant growth regulators and pesticides protection of meiotically unstable elite genotypes.

Analytical tools

Comparative aid for zygotic embryogeny

Production of large numbers of identical embryos

Determine role of endosperm in embryo development and germination

Study of seed coat formation

The synthetic seeds so developed breed true.

There are potential advantages of artificial seed technology specially for tree genetic engineering.

The artificial production of seeds has already been obtained successfully, in Zea mays, Apium gravelleus, Daucus carota, Lactuca sativa, Medicago sativa, Brassica spp, Gossypium hursutm, Santalum spp etc.

The encapsulation of somatic embryo (hydrated or desiccated) provides a potential method to combine the advantages of clonal.

Propagation with the low-cost high volume capabilities of seed propagation.

These seeds can be produced within a short time (one month) whereas natural seeds are the end product of complex reproductive process and breeders have to wait for a longtime for development of new variety.

Artificial seeds can be produced at any time and in any season of a year.

They are useful in preserving germplasm.
They are applicable for large scale monocultures as well as mixed genotype plantation.

The synthetic seed provide us knowledge to understand the development, anatomical characteristics of endosperm and seed coat formation. Such seeds give the protection of meiotically unstable, elite genotype.

Comparative advantages of artificial seeds over classical as well as micro-propagation (with short tip culture).

The rapid and large scale multiplication minimal labour and low cost propagation.

Artificial seeds can be directly delivered to the field. Thus eliminating transplantation and tissue hardening steps.

They can also provided with various kinds of adjuvants like plant growth regulators, useful micro-organism and pesticides to tailor a field specific. Plantable unit for a desired crop.

However, genetic uniformity is maintained in all there propagation methods. Artificial seed technology can be very useful for the propagation of a variety of crop plants, especially crops for which true seeds are not used or readily available for multiplication (e.g Potato). The true seeds are expensive (e.g Cucumber and Geraniums) hybrid plants (e.g. Hybrid rice) and vegetatively propagated plants which are more prone to infections (e.g. day lily, garlic, potato, sugarcane, sweet potato, grape and mango)

\section{Draw tissue culture principles}

The technique has developed around the concept that a cell is Totipotent concept that has the capacity and ability to develop into whole organism. The principles involved in plant tissue culture are very simple and primarily an attempt whereby an explain 
cannot be to same extent freed from interorgan inter-tissue and inter-cellular interactions and subjected to direct experimental unit. The most common culture in plant tissue is callus which is wound tissue composed of undifferentiated highly vacuolated and unorganized cells.

The concept of Totipotency of cells plant cells in vivo are not TiTopotent. Infact, with few exceptions, the only Totipotent cell is the fertilized egg. Some Tissues do not divide at all, other do so only occasionally. Meristems do divide but upon explanation are not capable of forming embryos. They are used, however in micro-propagation whereby new plants are generated via organogenesis. Some concept in science become inherently acceptable long before their practically is demonstrable. This was so in the concept of the totipotency of cells of higher plant. Even in the mid-twenties one encountered the Tact view that apart from inherent practical difficulties there was no theoretical reason why one e should not rear begonia plant from a single leaf hair cell. This view was traceable first to the then well recognized principles that as cells divide mitotically, they do equationally to produce daughter cells in Facsimile.

In plants, the mature embryo consists of a bipolar structure carrying meristems at the terminal ends. These meristems, consisting of somatic cells, will contribute to morphogenesis by generating new organs such as shoos, leaves, and roots throughout the adult phase of the plants. In vitro somatic cells may regenerate an entire plant via of the two alternation path ways.

Somatic embryogenesis, which reproduces the steps of Zygotic embryogenesis.

Organo-genisis, whereby under appropriate conditions (what matters is the auxin/cytokinin ratio) shoots and roots are generated in a sequential way, after adjustment of the hormonal conditions (Fig. $1)$.

\section{Somatic embryogenesis}

It is the process by which the somatic cells or tissue develop into differentiated embryo and each fully developed embryo is capable of developing into a plantlet (young or miniature plants).

Embryos can be obtained either directly from cultured explants (the organized structure, for example, leaf, hypocotyle, stem and other plants parts.) and anthers (or pollen) or indirectly from callus (unorganized mars of parenchymatious tissue derived from explants culture as a result of wound response) and isolated single cells in culture.

The process of embryogenesis involves various stages of differentiation and development such as proembryo, globular, heart-shaped and torpedo embryo.

\section{Achievements and prospects of synthetic seed technology}

\section{Somatic embryos}

Although various micro-propagules have been considered for synthetic seed production the somatic embryos have been largely favoured (Table 1) as these structures posses the radical and plumule that are able to develop into root and shoot in one step, usually without any specific treatment various types of artificial seeds have been prepared using somatic embryos which have been either dried or maintained fully hydrated, these may or may not be encapsulated (Kitto and Janick, 1999).

Onishi sakmoto and Hirosoma have demonstrated a protocol for the production of synthetic seeds involving automation at the production and encapsulation stages. 
These authors have emphasized that high and uniform conversion of synthetic seeds under a practical sowing situation, such as nursery beds in a green house or in the field, is an essential revilement for their use a clonal propagation of plants.

In tree species like santalum album, pistacia vera and Mangifera indica also the somatic embryos have been encapsulated to produce synthetic seeds, reported by Onay et al., (1996), Bapat et al., (1992), etc.
However, further research is needed to optimize protocols for production of viable synthetic seeds that could be stored for longer periods and could be commercially viable.

\section{Auxiliary shoot buds and apical shoot tips}

In many plant species (Table 1) the unipolar auxiliary shoot buds and / or apical shoot tips which do not have root meristems, have also been encapsulated to produce synthetic seeds.
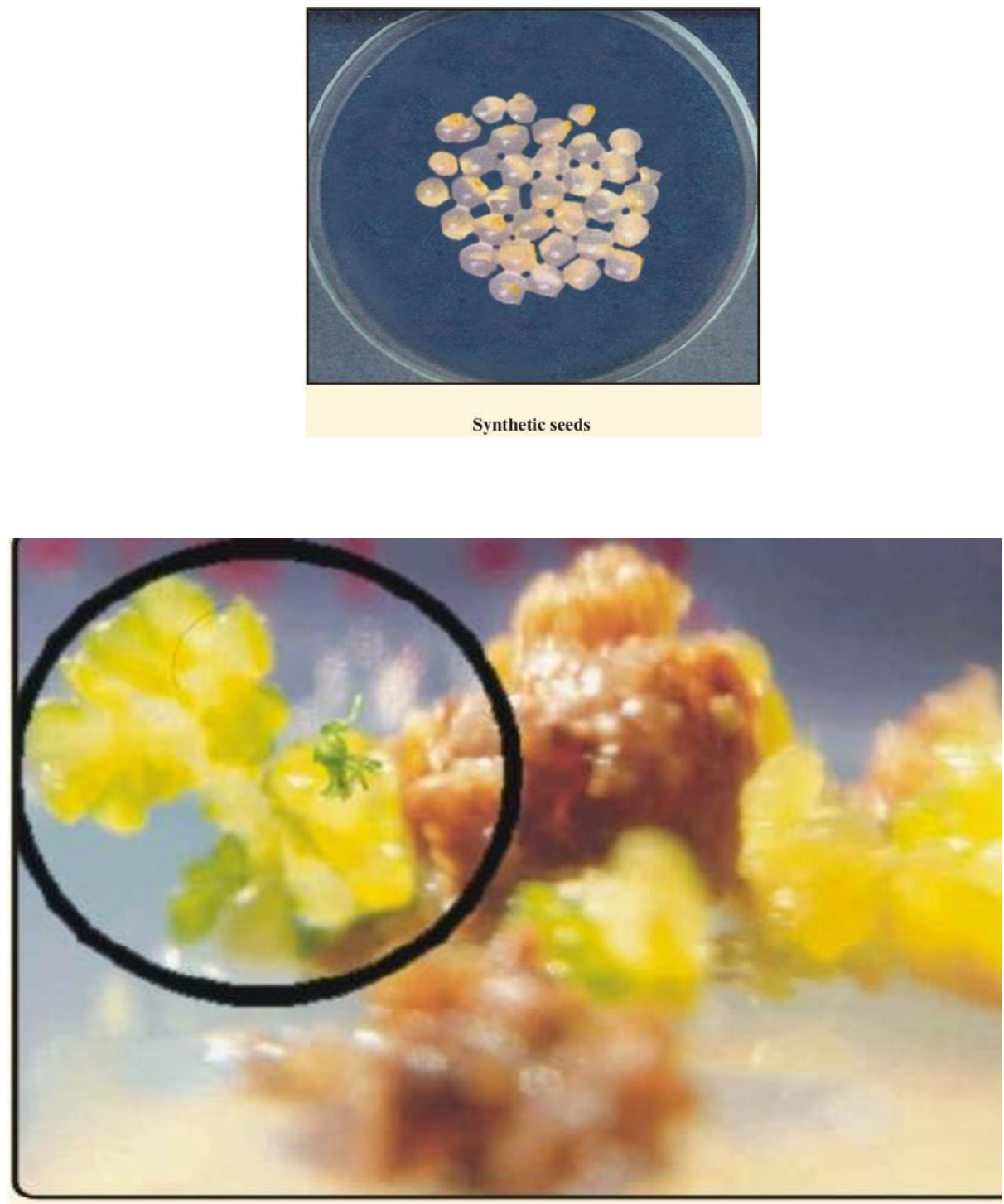

Somatic embryo's 
Procedure for production of artificial seeds

\section{Establish Somatic Embryogenesis}

\section{Mature Somatic Embryos}

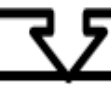

Syncronize and Singulate Somatic Embryos

Mass Production of Somatic Embryos

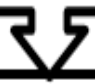

\section{Standardization of Artificial Endosperms}

3

Mass Production of Synthetic Seeds

$\checkmark 5$

\section{Greenhouse and Field Planning}

Fig.1 Effect of auxin treatments on callus and somatic embryo of carrot

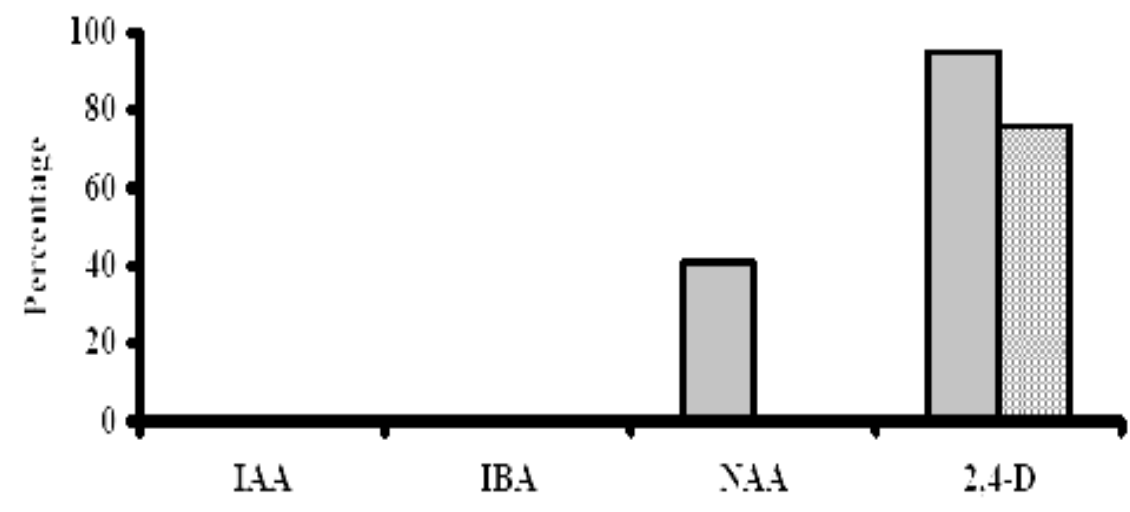

Auxin Treatments 
Fig.2 Germination efficiency of synthetic seeds of carrot on MS medium

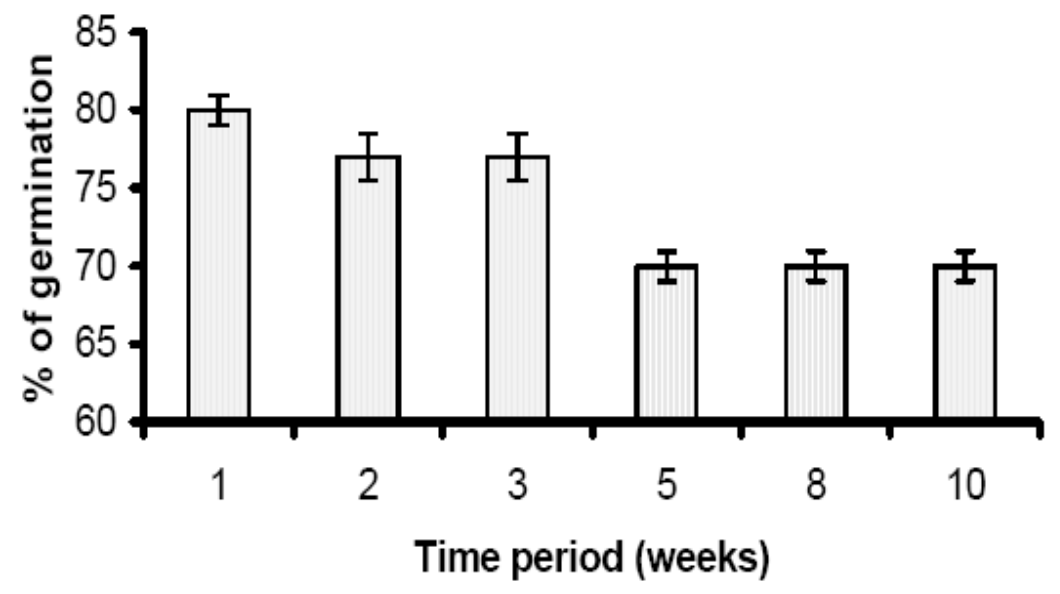

Table.1 List of plant species in which encapsulation technology has been applied to produce synthetic seeds

\begin{tabular}{|l|c|}
\hline Plant & Propagule used for encapsulation \\
\hline Actinidia delicosa (Kiwi fruit) & SB's \\
\hline Arachis hypogaca (Ground nut) & SE's \\
\hline Asparagus cooper & SE's \\
\hline Brassica comperiris (Mustard) & SB's \\
\hline Daucos ceroto (Carrot) & SE's \\
\hline Malus Punila (Mill) (Apple root stock M. 26) & SB's \\
\hline Mangifera indica L. (Mango cv. Amrapali) & SE's \\
\hline Psodium ghajana (Guava) & SE's \\
\hline Solanum melangena (Egg plant) & SE's \\
\hline Vitis Vinifera (Grape) & SE's \\
\hline Zingiber Officinale Pose (Ginger) & SB's \\
\hline Cucumber (Cucumis sativus) & SE's \\
\hline Poinied gourd (Trichosruthus dauca) & SB's \\
\hline Cynbidium gigenieum (Orchid) & PLB's \\
\hline
\end{tabular}

SB - Shoot bud, PLB - Protocol like bodies, SE - Somatic embryos

Sources: Ara et al., 2000; Latif et al., 2007; M. A. Malru, 2009; Tabassum et al., 2010

Table.2 Effect of different concentrations of sodium alginate on germination of artificial seed of pointed gourd

\begin{tabular}{|c|c|c|c|}
\hline $\begin{array}{c}\text { Sodium alginate } \\
(\boldsymbol{\%})\end{array}$ & $\begin{array}{c}\text { No. of seeds } \\
\text { cultured }\end{array}$ & $\begin{array}{c}\text { No. of seeds } \\
\text { germinated }\end{array}$ & $\begin{array}{c}\text { \% of seed } \\
\text { germination }\end{array}$ \\
\hline 3 & 40 & 16 & 40 \\
\hline 4 & 40 & 38 & 95 \\
\hline 5 & 40 & 12 & 30 \\
\hline Mean & 4.00 & 22.00 & 55.00 \\
\hline S.E $( \pm)$ & 0.000 & 8.083 & 20.207 \\
\hline
\end{tabular}

Significant at $5 \%$ and $1 \%$ level, respectively 
Table.3 Effect of different concentration and combinations of BAP and NAA on artificial seed proliferation from shoot tip explants of $A M-8$ and $A M-15$ genotype

\begin{tabular}{|c|c|c|c|c|}
\hline $\begin{array}{l}\text { Treatments } \\
\text { (mg/l) }\end{array}$ & $\begin{array}{l}\text { Days to shoot } \\
\text { proliferation }\end{array}$ & $\begin{array}{c}\text { \% of shoot } \\
\text { forming } \\
\text { explants }\end{array}$ & $\begin{array}{l}\text { Days to shoot } \\
\text { proliferation }\end{array}$ & $\begin{array}{c}\begin{array}{c}\% \text { of } \\
\text { shoot } \\
\text { forming } \\
\text { explants }\end{array} \\
\end{array}$ \\
\hline BAP 0.5 & $7-$ & $75-$ & $7-$ & $80 \pm$ \\
\hline BAP 1.0 & $7-$ & $85++$ & $7-$ & $90+ \pm$ \\
\hline BAP 1.5 & $7-$ & $70-$ & $7-$ & $72-$ \\
\hline BAP 2.0 & $7-$ & $55-$ & $7-$ & $58-$ \\
\hline Mean & 7.00 & 71.25 & 7.00 & 75.00 \\
\hline S.E $( \pm)$ & 0.000 & 6.250 & 0.000 & 6.757 \\
\hline NAA 0.5 & 8 & $65+$ & 8 & $70+$ \\
\hline NAA 1.0 & 8 & $70++$ & 8 & $75++$ \\
\hline NAA 1.5 & 8 & 45 & 8 & 47 \\
\hline NAA 2.0 & 8 & 30 & 8 & 30 \\
\hline Mean & 8.00 & 52.50 & 8.00 & 55.30 \\
\hline S.E $( \pm)$ & 0.000 & 9.24 & 0.000 & 10.460 \\
\hline $1.0+0.5$ & 8 & 55 & 8 & 60 \\
\hline $1.0+1.0$ & 8 & $75++$ & 8 & $80++$ \\
\hline $1.0+1.5$ & 8 & 50 & 8 & 55 \\
\hline $1.0+2.0$ & 8 & 30 & 8 & 35 \\
\hline Mean & 8.00 & 52.50 & 8.00 & 57.50 \\
\hline S.E $( \pm)$ & 0.000 & 9.242 & 0.000 & 9.242 \\
\hline \multicolumn{5}{|l|}{$\mathrm{NAA}+\mathrm{BAP}$} \\
\hline $1.0+0.5$ & 9 & 50 & 9 & 60 \\
\hline $1.0+1.0$ & 9 & $75++$ & 9 & $80++$ \\
\hline $1.0+1.5$ & 9 & 50 & 9 & 55 \\
\hline $1.0+2.0$ & 9 & 40 & 9 & 40 \\
\hline Mean & 9.00 & 53.75 & 9.00 & 58.75 \\
\hline S.E $( \pm)$ & 0.000 & 7.465 & 0.000 & 8.260 \\
\hline
\end{tabular}

Significant at $5 \%$ and $1 \%$ level, respectively

Since these structures do not have root meristems they should be induced to regenerate roots before encapsulation, ricconi and standard have described conversion of shoot buds of apple clonal rootstock M. 26 encapsulated after an appriate root induction treatment with IBA $(24.6 \mu \mathrm{m})$ for 3-6 days.

\section{Embryogenic masses}

Stable and regenerative embryogenic masses make an attractive tool for the production of clonal plants and for studies of genetic transformation. However, long term maintenance of embryogenic masses in culture tubes or mechanically stirred bioreactors resources frequent transfer of tissue to fresh media which is both labour intensive and costly.

\section{Protocorms or portocorm like bodies}

In orchids such as Cymbidium giganieum, Deudrobim wardianum, Geodorum 
densiflorum, Phaius tonkervillae and Spathoglotis plicata synthetic seeds have been produced by encapsulating the protocol like bodies (PLB's) in sodium alignate gel Corrie and Tandon have reported that the encapsulated to healthy plantlets upon transferring either to nutrient medium or directly to sterile sand and soil. These techniques have made it possible to transplant to areptically grown protocols directly in the soil, cutting down the cost of raising in vitro plantlets and their subsequent acclimatization.

Production of synthetic seed has been reported in a number of cereals, tuberous plant, vegetables and other commercially important plants like soya bean, mustards, coffee, tobacco and cotton (Datta et al., 1999). However, because of certain inherent obstacles, the production rate of the uniform and high quality embryo is lower. Consequently the preparation of efficient and quality seed has been successfully in only a few crops like carrot (Latif et al., 2007) and alfalfa (Datta and Poirythus 1989). The primary goal of artificial seed system is to regenerate whole plantlets form artificial seeds.

First report of genetically uniform production of synthetic seeds was in cucumber by standardizing culture conditions to induce somatic embryogenesis synchronously and at high frequency in cell suspension culture through following steps (Tabassum et al., 2010)

\section{Callus induction}

Friable, nodular and embryogenic callus is considered pre-requisite to establish fast growing cell suspension culture and subsequent regeneration. The hypocotyle pieces of Royal cultivars developed into callii when cultured on MS-media continuing 2.0 $\mu \mathrm{M}, 24 \mathrm{D}$ and $0.5 \mu \mathrm{N}$ BAP with $3 \%$ sucrose.

\section{Cell suspension}

Following callus induction, cell suspension of cv. Royal was established in its respective callus induction media. Best suspension culture was obtained from MS-media containing $3 \%$ sucrose, $30 \mu \mathrm{M}$ adequate sulphate, $3 \mu \mathrm{M}$ thiamine $\mathrm{Hcl}, 580 \mu \mathrm{M}$ $\mathrm{NaH}_{2} \mathrm{PO}_{4}, 0.1 \% \mathrm{CH}, 5 \mu \mathrm{M}$ NAA and $1 \mu \mathrm{M}$, BAP. Cultures were placed on a gyratory shaker with rotation at $30 \mathrm{rpm}$ at $22 \pm 2{ }^{\circ} \mathrm{C}$ for $16 \mathrm{~h}$ photoperiod.

\section{Synchronization of embryogenesis}

The procedure adopted by Givilano et al., (1983) to synchronize the cucumber cell suspension was followed. All cells were subcultured and passed through $150 \mu \mathrm{M}$. Steve (100 mesh) after every 10 days sub-culturing and then incubated an gyratory shaker at 80 $\mathrm{rpm}$ at $22 \pm 2^{\circ} \mathrm{C}$. After two successive subculturing, cells at globular stage were shifted onto modified suspension media containing $\mathrm{CH}$ and NAA only. Cells turned into heart and torpedo shapes after 2-3 days. They were then sub-cultured on MS basal media, devoid of growth regulators which helped in uniform maturation of somatic embryo.

\section{Synthetic seed / encapsulation}

Mixture of mature cell suspension and sodium alginate at a ratio of 1:4 were dropped into $100 \mathrm{mM}$ calcium chloride solution to form synthetic seeds.

\section{Regeneration efficiency of synthetic seeds}

Shoot formation was observed when synthetic seeds were placed on neutral gel formed by dissolving phytagel in autoclaved tap water. The test tube containing neutral gel plus synthetic seeds were kept for $16 \mathrm{~h}$ photoperiod at $22 \pm 2^{\circ} \mathrm{C}$. shoots enlarged upto 10 days in neutral gel media when 
appropriation temperature and humidity were provided.

\section{Indigenous production of synthetic seeds in} Daucus Carota

A study was carried out in DAUCAU CAROTA for indigenous production of synthetic seeds by Latief et al., (2007) through following steps:

\section{Embryogenic callus formation}

Most important factors for induction of Embryogenic callus and plant regeneration through somatic embryogenesis includes Explants type, Media formulation, Growth regulators. Most important factor that affected callus type was the growth regulator. It was found among growth regulators like IAA, IBA, NAA and 24, D - which were used for induction of somatic embryogenesis 24, D was significant for inducing the somatic embryogenesis.

\section{Suspension culture}

After embryogenic callus induction, cells were proliferated on both modified MS solid and liquid medium containing $\%$ casein hydrolyrate and $2 \mathrm{mM}, 2.4-\mathrm{D}$ cell suspension were cultured on a rotary shaker $(120 \mathrm{rpm})$ under the same conditions as for callus formation.

Synchoronization of embryogenesis. The procedure followed those of Giulano et al., (1983).

Encapsulation with alginate gel.

\section{Germination efficiency of synthetic seeds}

Germination frequency of synthetic seeds was checked upto 10 weeks. Thirty seeds were grown on MS basal medium at $25^{\circ} \mathrm{C}$.
Germination generally occurred in 6-8 days. After 3 weeks the germination frequency was stable (Fig. 2).

In vitro propagation of pointed gourd (Trichosanthes dioica Roub) through encapsulated shoot tips

A study was carried out in pointed gourd by M. A. Malik, 2009 in which shoot tips were taken in vitro grown plantlets for artificial seed production. Two genotypes of pointed gournd (AM - 8 and AM - 15) were used to exhibit different levels of morphogenic growth response in tissue culture media. The encapsulated shoot tips were cultured in MS (Murashige and Skoog, 1962) agar gelled media supplemented with different concentration and combinations of BAP $(0.5$, 1.0, 1.5 and $2 \mathrm{mg} / \mathrm{l})$ and NAA $(0.5,1.0,1.5$ and $2.0 \mathrm{mg} / \mathrm{l})$. To investigate the induction of shoot regeneration, data on days to shoot proliferation and percentage of shoot forming explants were recorded after culture of encapsulated shoot tips (Table 3).

Encapsulation of shoot tips in sodium alginate

In the present study, various concentration of sodium alginate were tested to find out the optimum level of encapsulation for production of artificial seeds. Among the various concentrations of sodium alginate tested, best results were obtained with $4 \%$ alginate. Higher and lower levels of sodium alginate reduced the conversion frequency (Table 2).

Redenbaugh et al., (1987) noted that variables related to encapsulation, method including alginate type and concentration, medium and methods used to produce the synthetic seeds were responsible for significant variation in conversion percentage for alfalfa, carrot and celery. 


\section{Limitations}

Although results of intensive researches in the field of synthetic seed technology seem promising for propagating of number of plant species, practical implementation of the technology main reasons:

Limited production of viable micropropagules useful in synthetic seed production.

Anomalous and synchronous development of somatic embryos.

Improper maturation of the somatic embryos that makes them inefficient for germination and conversion into normal plants.

Lack of dormancy and stress tolerance in somatic embryos that limit the storage of synthetic seeds.

Poor conversion of even apparently normally matured somatic embryos and other micropropagules into plantlets that limit the value of the synthetic seeds and ultimately the technology itself.

Development of artificial seeds requires sufficient control of somatic embryogeny from the explants to embryo production, embryo development and their maturation as well. The mature somatic embryos must be capable of germinating out of the capsule or coating to form vigorous normal plants. A number of researchers have tried to improve the quality (Attree et al., 1991) and quantity (Ara et al., 2000) of somatic embryos via modification of culture conditions, such as medium composition, growth regulator (types and concentrations), physical state of the medium, as well as incubation conditions like temperature, illumination etc.

Despite considerable research input into artificial seed production during the last fifteen years, several major problems remain with regard to its commercialization. The first requirement for the practical application of the artificial seed technology is the large scale production of high quality micro-propagules, which is at present a major limiting factor. Additional factors responsible for poor germination of synthetic seeds are the lack of supply of nutrients and oxygen, microbial invasion and mechanical damage of somatic embryos. In fact conversion is the most important aspect of the synthetic seed technology and still remains one of the factors limiting commercial application of this technology. Occurrence of high levels of soma clonal variations in tissue culture is another aspect to be considered seriously while recommending the use of artificial seeds for clonal propagation.

One of the future usage of synthetic seeds would be in germplasm conservation through cryopreservation. Either hydrated calcium alginate based or desiccated polyongethylene glycol based artificial seeds might be used, but it is likely that some degree of drying before cryopreservation would be beneficial.

The synthetic seed technology offer tremendous potential in micro-propagation and germplasm conservation, however further research is needed to perfect the technology so that it can be used on a commercial scale.

\section{References}

Attree, S. M, Moore, D., Sawheny, V. K and Fowke, L. C 1991. Ann. Bot, 68:519525

Bapat, V.A and Rao, P.S. 1992. J. Plant BioChem, Biotechnol., 1: 109-113

Brar. D. S. and Khus G. S, 1994. Cell and Tissue culture for plant improvement.

Bushra Tabassum, Idrees Ahmed Nasir, A. M. Farooq, Z. Rehman, Z. Latiff and T. Hussain 2010. African J. or 
Biotechnology Vol 9 (42) Pp-70267032.

Corrie, S. and Tandon, P., Indian J. Exp. Biol. 1993, 31: 61-64

Datta KB, Kanjilazro B, Sarkar DDE (1999). Artificial seed technology development of a protocol in Geodorum devsiflora (Lau) Schltr an endangered orchid, Mord, G.M., Ann. Orchid Soc. Bull 1960 (29) 495-497.

Datta SK, Potrykus (1989). Artificial seed in barley, encapsulation of microspore derived embryos theory. Appl. Genet. 77: 820-824

Drew R. L. K 1979. A cheap, simple apparatus for growing large batches of plant tissue in submerged liquid culture plant Sci. Letter, 17, 227-236

Giuliano GD, Rosellini D, Terzi M. (1983). A new method for the purification of the different stages of carrot embryoids plant cell tissue organ cult. 17: 191-218

Gray, D. J and Purohit, A. 1991. Critical REviw Plant Science, Vol. 10 Pp-33-61

Hussain Ara, Uma Jaiswal and V.S Jaiswal 2000. Synthetic seed: prospects and limitations.

Jawck, J., Wright, D.C and Hasegawa P. M. 1982. In vitro propagation of cocauseed lips. J. Amer. Soc. Hort. Sci, 107: 919 922

Kitto, S and Jawck, J. 1985. Production of synthetic seeds by encapsulating asexual embryos of corrot James, SOC Hort. Sci. 110: 277

Latief Z, Nasir I.A and Riazuddin S (2007) indigenous production of synthetic seeds in Daucus carota Pak, J. Bot. 39 (3): 849-855.

M. A. Malik, 2009, In vitro propagation of pointed gourd (Trichosauthes dioca Roub). Through encapsulated shoot tips. Bangladesh J. Agri. Res. 34 (4) Pp-555563

Murashige, I. and Skoog, F. 1962. A revised medium for rapid growth and bio assays with tobacco tissue culture, Physio. Plant 15: 473-490

Murashige, T nd Skoog, F 1962. A revised medium for rapid growth and bio assays with tobacco tissue cultures. Physiol, Plant 15: 473-497.

Onay, A. Jeffree, C. E and Yeoman, M. M. 1996. Plant cell Rep., 15: 723-726

Redenbaugh K, Parrch, B. D. Nichol, J.W. Korslee M. E. Viss, P.R and Walker, K. A. 1986. Somatic seeds encapsulation of asexual embryos Bio/Tech 4: 797801

Redenbaugh, K., Horti. Sci. 1993, 25, 251255

Riccioni, E, 1997. Plant cell tissue org. cult. 47: $255-260$

\section{How to cite this article:}

Mudasir Magray, M., K.P. Wani, M.A. Chatto and Ummyiah, H.M. 2017. Synthetic Seed Technology. Int.J.Curr.Microbiol.App.Sci. 6(11): 662-674. doi: https://doi.org/10.20546/ijcmas.2017.611.079 